\title{
A Feminist Reading of Filipino Women Poets
}

\author{
Jennie V. Jocson, PhD \\ Philippine Normal University, Philippines. ORCID: 0ooo-0oo2-0042-2962. \\ Email: jocson.jenniev@gmail.com
}

\begin{abstract}
This paper draws on ideas from a shared identity of Filipino women writers. While a shift in $21^{\text {st }}$ Century feminist reading, mainly the slant that to think about woman is also to think about gender, has become available for interrogation and re-inscription, the study on Filipino woman as a construct and a subject of self-representation of contemporary Filipino poetry remains scarce. Drawing at how women and their experiences were represented in select poems written by 4 contemporary women poets, this paper explored common patterns of women imaging using textual and thematic analysis, alongside French feminism expounded by the arguments of Helene Cixous, Luce Irigaray, and Julia Kristeva. The findings revealed that women poets' rhetoric, awakening, resistance, and call to action had redefined women experience as a collective whole. Collective as they seem, the poems established a strong articulation of a feminist stance, which is a resistance against subversion and marginality. The paper is of relevance both to feminist scholars and others with practical interests in women poetry as it will enable them to better understand Filipino women experience and its representation in verse.
\end{abstract}

Keywords: Filipino women, feminist, poetry, representation, imaging.

\section{Introduction}

In Asian nations, "gender was a relative latecomer when it entered the discourse in the 1990s" (Chin \& Mohd Daud, 2018, p. 6). As feminist writing becomes a favorite topic in the West, Asian women were less valued as they were always considered 'nothing without men,' 'inferior,' 'incidental being,' and even 'a sin.' With the growth of interest in women over the years, literatures about women representations give a rather diverse position. On one hand, their representations suggest that they have been oppressed, repressed, and suppressed. Women in various fields have been proven inferior to the intelligence, abilities, and thoughts of men (Kintanar, 1992; Wright \& Hilario, 2016). On the other hand, there are women representations, which highlight their dissatisfaction on everything male. Most of these studies are linked with a common thread, which is to say, to celebrate the ways in which so many women have beaten the system, taken charge of their own destinies, and encouraged each other to live, love, and laugh and be happy as women (Tong, 1989; Coward, 1990).

A representation plays a key role in regulating, producing, and reconfiguring woman identities as it presents images wherein meanings are attached. A meaning is associated with a flow involving reader's emotional response (Coady \& Johannessen, 2006; Csikszentmihalyi, 1990; Rosenthal, 1995; Wright, 2017) that stimulates a "mode of engagement as an enactive form of identification” (Fialho, 2009, p. 2). Hence, an inferior presentation or imaging is dangerous, to say

(C) AesthetixMS 2020. This Open Access article is published under a Creative Commons Attribution Non-Commercial 4.0 International License (http://creativecommons.org/licenses/by-nc/4.o/), which permits non-commercial re-use, distribution, and reproduction in any medium, provided the original work is properly cited. For citation use the DOI. For commercial re-use, please contact editor@rupkatha.com. 
the least. While feminist discourse and woman ideologies in Asia, particularly in the Philippines, were arguably influenced by those who have been educated in and by the West. Women writers someway make women visible in local and national imaginaries (Boehmer, 2005; Choi, 2019). However, only a handful poets have reached the stature of male writers.

Women narrators and characters' use of "multiplicity of voices to detail their awareness of their position in the modern world" (Campbell, 2000, p. 91). From Jane Austen of the $18^{\text {th }}$ century to George Eliot of the $19^{\text {th }}$ century, novels written by female writers have moved, despite many restrictions, in the direction of an all-inclusive female realism. Writers like Arundhati Roi (Indian), Carmen Martin Gaite (Spanish), Anita Desai (Indian), Maxine Hong Kingston (Chinese American) and Ninotchka Rosca (Filipino) have proven that there is a concrete effort to unify the oppression of women to establish a woman's liberation and literary tradition.

Poetry of and about women does not only emphasize women sensitivities but also elicit distinguished responses as to how they are imagined and represented. It is partly through the contemplation and practice of women's poetry that the Filipino literary tradition slowly shaped a "female tradition." Women poets have slowly evolved into a formidable literary stage. The building of this literary stage for women poets does not only make Asian literary tradition richer, but also does allow women poets to voice out their experience, self-representations, and ultimately, share women's position in the world while "deterritorializing masculinist positions and spaces" (Chin \& Mohd Daud, 2018, p. 10). Therefore, it is of interest to problematize poetry using key concepts of feminist tradition expounded by Helene Cixous (1981) and Luce Irigaray (1985) while drawing on ideas from a shared identity of contemporary Asian women poets to articulate a feminist stance-- a resistance against subversion and marginality.

\section{Feminism in Literature}

Aside from shifting theories within its realm, Feminist Criticism has also flourished in combination with every other critical approach. The result is the altercation of the worldviews on women and their roles. Whether concerned with the literary representations of sexual difference, with the ways literary genres have been shaped by masculine or feminine values; or with the inclusion of the female voice from the institutions of literature; feminist criticism has established gender as a fundamental category of literary analysis (Johnson, 1985). Feminist theorists like Simone de Beauvoir (1949), Kate Millet (1970), Susan Griffin (1979) among others have tried to reconstruct the image of women as a writer by laying the source of authenticity and reality (Humm, 1992).

In recent years, a paradigm shift in feminist literary criticism has emerged. The meaning of woman as a signifying term is subject to its most radical destabilizations, thereby influencing what it means to be a feminist or to practice feminist literary criticism that undergoes meaningful change (Oliver \& Walsh, 2004). To think about women was also to think about gender such as masculinity and femininity that became available for interrogation and re-inscription. Feminism began to ask fundamental questions regarding language and human subjectivity, and these questions were, simultaneously, the subject of intense debate in a range of complementary theoretical discourses, from linguistics to psychoanalysis. New forms of feminist literary criticism emerged while continuing to examine the complexity of gendered identities in contemporary society.

New debates emerged questioning the status of the term 'woman' as a coherent theoretical point of origin. In particular, feminist critics Helene Cixous (1981), Luce Irigaray (1985), and Julia Kristeva (1982) suggested not the dismissal, negation, or censorship of a certain concept, rather requires its 'critical reinscription and redeployment. Allison (2007) aptly pointed out that to 
deconstruct from the feminist point of view is to fully understand and analyze the concept, ideas, and rules regarding women's nature and her ultimate role in the society.

\section{Methodology}

Anchored heavily in the arguments of Helene Cixous, Luce Irigaray, and Julia Kristeva, including textual and thematic analysis, this study explored the representations of Filipino women in select 5 poems written by women poets. The poems under study were discussed with emphasis on political, social, even historical constructs to provide a clear, if not exact image of women. The choice of Filipino women poets was based on their inclusion in the Philippine curriculum for literature. Further, the chosen poems are all written or translated in English.

\section{Results and Discussions}

\section{Tribeswoman}

Marra PL. Lanot

1 My body contains

2 The dream of my father

3 Sweat of my husband

4 Hope of my children ...

5 But could it be possible

6 It is wrong

7 To stand and wait

8 Like this ---a heap of ribs,

9 A forsaken idol ---

10 As my foremothers

11 Did before me

12 Many moons ago

13 In the shadow of the mountains?

14 Could it be possible

15 It is wrong?

16 Could it be

17 Possible?

Even at the opening lines, a strong tone in Lanot's poem is evident. The sense of anger pervades in the entire poem, and it grows stronger as the persona describes herself and later asks for help and support. These lines link to the inner world of the persona when she says:

My body contains

The dream of my father

Sweat of my husband

Hope of my children. (lines 1-4) 
The persona opens with history -she is a "vessel," a "carrier.' She then shifts to ask what she is, and who she has become based on the concrete points raised for her by her society. She has reservations on how she looks at herself and as an immediate effect, the reader is likewise led to question these cultural and social constructs. However, notice the tone of the question - "Could it be?" This question was asked with a tinge of innocence, even perplexed. There was pure yearning for the readers to comprehend where she was coming from. Lines 7-8 reflect how the persona sees her life, which is a repetition of the past of her "foremothers" "many moons ago" "in the shadow of the mountains." She sees history picturing her and that of the women before her as only "a heap of ribs" standing and waiting, being nothing but so.

Could it be possible?

It is wrong

Could it be

Possible? (lines 14-17)

The last rhetorical lines of the poem depicts urgency on the persona's end for readers to identify with her, understand her, and probably, believe her.

Fear

Sarah Gambito

1 A girl as a gem. I saw the worthiness of a gem.

2 But I was not the gem and I was not the jeweler.

3 One thousand people gather for the resurrection.

4 Their duty to the commonplace.

5 She's waiving as if she might lose. She is your sister.

6 A corona. A beggar of lilies.

7 A platform for the operetta to begin.

8 Bring in the butcher and his life in service

The poem opens with direct information, "a girl is a gem." The persona immediately draws readers to her world where she sees the girl as a worthy gem. However, she ruins the beautiful and perfect images created in readers' minds when the persona continues "I was not a gem and I was not a jeweler" (line 2). She did not prepare the readers for this sudden change of tone and was not even apologetic. Lines 3-6 presents a situation and allows the readers to survey the place by specifying that there is a gathering of "a thousand people." This time, she directs the gaze to a woman who is "waving as if she might lose." She describes her as everyone's sister who waves frantically to call attention. Was she in pain or in need? She yearns for the undivided attention and the succeeding lines explain. Meanwhile, line 6 reflects a binary, "corona and a beggar of lilies." The former shows grandness, even superiority, while the latter depicts a low class and inferior. Therefore, she waves to be noticed to show a life of uncertainty, of binaries. Ultimately, when one thinks of the ambiguity of the place "for the resurrection." The place of resurrection gathers women related to each other, sisters, hence, this place reflects the time the sisters gather. More than just a 
physical place, this place of resurrection creates 'oneness'- sharing of thought and preparing for the "operetta to begin" (line 7). She is with the rest like her, looking for attention, finding a place to be recognized. Finally, the poem accounts for an overwhelming contradiction set by the persona-- she is not a gem, because she has suffered, she has endured. Maybe, she begins to see herself in a fitting light as she closes, "bring in the butcher and his life in service."

Batgirl

Sarah Gambito

1 Don't want to invite those darker envelopes of me waistband

2 In the book's bible darkness.

3 I have sentiments and pretty candy and snowmen.

4 And snowmen who adore me.

5 And I'm angry

6 And I leave the concert area quietly in my batgirl pleather.

7 So everyone looks at me, me, me.

8 And I apologize because I'm supposed to.

9 And I rival your friend

10 Who flew with you as you were sad to "New York."

11 Where mortals drink brandy in my getting-expensive café.

The persona resents the fact that people around her notice her. She says, "so everyone looks at me, me, me" (line 7). She dislikes the idea that due to such attention accorded her, she goes quietly, in her batgirl leather, as if to lose the 'gaze' on her. She had to 'leave' her usual world to return to her own world, where she can be herself. What seems recognizable is the persona's strength of character. Line 8 states, "And I apologize because I'm supposed to" and continue to the next line- "And I rival your friend." She does not offer any chance of apology for being who she is, for doing the things she did. The 'Batgirl' signifies a woman ready for flight, can fly and leave because she is angry and not afraid to say so.

\section{Father and I}

Maningning C. Miclat

1 The leaves are shaking,

2 "Look. It's the wind!"

3 You said, "No, those are leaves.

4 Wind cannot be seen."

5 Snowflakes whirl down

6 An emblem of purity.

7 You said, " No, it is deception.

8 It is here to cloak the filth."

9 A lovely object

10 Took my fancy.

11 You said, "It's Useless." 
12 I haven't walked too far,

13 But I am feeling tired.

14 Let me rest by the path for a while.

15 When the wind blows, I feel it.

16 When snow swirls down, I see it.

17 The lovely object I hold in my hand.

The poem underscores the relationship between a father and a daughter. The persona laments over the kind of relationship she has with her father. One is shown with the sad state of their relationship when the persona talks of a day's conversation. As she asks and points - "look, it's the wind," "snowflakes whirl down- an emblem of purity," "a lovely object" - the father dismisses"No, those are leaves, wind cannot be seen," "no, it's deception." "It is here to cloak the filth," "it's useless." The persona continues to lament that she feels tired of the situation. She further feels that she was dismissed not only because she talked and gave her opinions but also she was a 'she,' a daughter, a woman. As the poem ends, when the persona felt tired of how the father treats her, she stops and talks against his rule. She takes on her courage to correct her father:

When the wind blows, I feel it.

When the snow swirls down, I see it.

The lovely object I hold in my hand. (lines 15-17)

The lines resonate with a clear tone of anger. A change of tone and attitude towards the father is projected. The evident 'anger' seems to show that she has reached a point of determination and fighting back. Does this mean lack of respect to a parent? The poem talks more of a general father, who for so long, 'silenced all daughters' of the world. As the persona reaches that all too important turning point of resistance, all women share her 'freedom.'

\section{Caravan of the Water bearers}

Marjorie Evasco

1 We will not forget the evil eye

2 Of the storm they raised,

3 Gutting the grounds they defended.

4 We have been trained

5 Too look away too often

6 When man's flesh, muscle, bone,

7 Knifed woman to protect

8 The child's eye from the dust

9 Of the lord's sin against

10 Our kind, pretending

11 Our tears are daughters of the wind

12 Blowing across no- woman's- land.

13 We have had to seek the center

14 Of the storms in the land we claim

15 Is ours, too. Faces keening towards

16 The full force of winds

17 Once blinding us, we see 
$7 \mid$ A Feminist Reading of Filipino Women Poets

18 The blur of broken earth,

19 Blasted wastes, damned seas.

20 Our vision clears in our weeping

21 We have joined the trek

22 Of desert women, humped over

23 From carrying our own oases

24 In the clay pots of our lives,

25 Gathering broken shards we find

26 In memory of those who went

27 Ahead of us, alone.

28 when we seize the water source

29 our ranks will complete the circle

30 we used to mark around our tents,

31 making homes, villages, temples,

32 schools, our healing places.

33 And we will bear witness for

34 Our daughters and sons,

35 Telling them true stories

36 of the caravan.

The poem reflects that "integrated self" that connects to a whole tradition and culture of women tagged as water bearers. A caravan is a group of travelers moving towards one path, one goal. Evasco depicts a group of carriers who revealed with certainty a war against the rule of the dominant male. The dominant male looks at them as unimportant, fleeting, and unable to hold shape. The personae are taken as weak, having been trained, and deemed pretentious. This anger shared by all water bearers tells an experience shared by all. Collectively speaking, the personae strengthen their call for change and against the rule of the father. They take this strength and anger after those who went before them - those who fought back and those who try to get their 'water source.' As such, they try to complete the circle of this caravan to claim what is theirs- the water source, contrary to the claims of the dominant male. Unlike how their eyes were made to see in the past, they will serve the true caravan by speaking of the truth, politically correcting the history for their sons and daughters.

\section{Woman's rhetoric}

French feminism, particularly the theories of Helene Cixous (1981) and Luce Irigaray (1985), accounts for a woman's language unlike those understood and learned from a society solely driven by patriarchy. Irigaray (1985) examines the way women speak to each other and disrupt symbolic or social language. She shows how a more adequate representation of women's differánce, particularly physical aspects of her sexuality, can reveal how a woman's identity assumes a continuous fluidity. Contrastingly, Cixous (1981) claims a language, a rhetoric of praising own bodies, creates new identities for women and eventually can establish new social institutions. The poems in this study revealed such language that Irigaray and Cixous defined. The poems described a concerted effort to interrelate the myriad forms of women's expression to achieve synthesis, thereby producing a determined unity and integration against men. Lanot's Tribeswoman used language which reflects a force imitating, or better yet, metaphorizing the structural culture. 
A more concrete understanding of the poems revealed how women used the nuances of language that only them had a better understanding. As a result, women are taken as unnecessary and unimportant, even undetermined. What men do not see, if not refuse to see, is that women look at themselves clearly in a language purely their own, devoid of anything outside who they are. Its implication is that women view themselves in relation to each other. Evasco's Caravan of the Waterbearers, Gambito's Fear and Batgirl employed a language reflective of her own voice: sister in experience and motherhood. The more diverse a woman's opinion of herself is, the more man falls into an abyss of doubts, self-preservation, and confrontational stance. Worst still, man culturally and socially, has refused to "see" woman. In Miclat's Father and I, the language expresses an evident 'anger' as she reached a point of determination and fighting back.

The rhetoric of poetry speaks of a woman's moment that Irigaray calls woman's time (1985) when there is no care at all to how they will be 'seen' and 'glossed' over. Admittedly, from a deconstructionist lens, the woman-personae's language reflects a lot of binary oppositions that the cultural and the social patriarchy see as part of their weakness, let alone inability to express. But for the women themselves, the dichotomies they present themselves with are constructs of their images. Instead of viewing these dichotomies as part of their weakness, they serve as their pillars of strength. For their very beings as women, they are fluid, patternless, structureless, therefore limitless.

\section{Woman's awakening}

The evolution of feminist thought describes the focus of what de Beauvoir (1949) termed as the second sex or the Foucauldian notion of the other. Jean-Paul Sartre's theory of Being and Nothingness (1956) accounts, among other things, for being-in-itself (en soi) and being-for-itself (pour soi). The former refers to the constant, material existence that humans share with animals, vegetables, and minerals, whereas the latter refers to the moving, conscious existence humans share only with other humans (Sartre, 1956). The woman being the 'other' refers to herself as part of that being-for-itself to see that her otherness brings forth a more distinct understanding of her woman-ness. Seeing herself for the very first time, a woman can step into the moment of awakening, thereby avoiding anything that a culture or society dictates her.

Sarah Gambito mixed her language and the logic of dichotomies to record a woman-persona who gives a new meaning to the word fear. Her reflections carried through in lines 1 and 2, the dichotomies of the emotions of the woman-persona, "A girl is a gem. I saw the worthiness of a gem, but I was not the gem and I was not the jeweller." The persona acknowledges the gem as worthy. A metaphor of seeing herself as a gem, as worthy, despite the second line saying otherwise. She further notes that she "is not a jeweller" to mean plurality of the feminist psyche. Her self-representation is comparable to having no wilderness that is complete in the clearing. The poem continues, "She's waving as if she might lose. She is your sister" (line 6), requiring a more concrete awakening to recognize a sister - a process of gendering the text. In comparison, Gambito's Batgirl resents the idea of seeing the woman-persona ("so everyone looks at me, me, me "- line 7). It presents a victim who is aware of male dominance and women stereotypes. As she points out that the result of such resentment, an apology was made (line 8). It indicates the pressure the persona feels. In lines 1-3, the woman-persona reveals a different level of sentiments, "Don't want to invite those darker envelopes of me waistband. In the book bible darkness. I have sentiments and pretty candy and snowmen." 
Gambito's poems depict women's awakening that tarries through changes in emotions, representations, and resentments. Gambito's women understand what a society expects from them and that is crystal clear. When they follow, they do not intend to diminish themselves or accept defeat. They triumph by penetrating the male world. The "natural order" as what Rosemary Tong defines (1989, p. 87) does not work for them since they come up with a new order of things where a woman dominates. Gambito's poem declares that she is an awakened woman who sees how the father views her and as such, allows her to counterattack.

In Father and I, Maningning Miclat mirrors an existing structured relationship between a father and a daughter. The poem shows how a daughter asserts herself against the ruling father. Psychologically, the woman-persona suffers from the rejection of the father, as he becomes indifferent even to simple things or ideas the daughter holds on to. It seems enough to make her think that it is because she is a woman. As she gets tired:

I haven't walked too far.

But I am getting tired.

Let me rest by the path for a while. (lines 12-14)

Realizing the sad reality of her relationship with the father, she fights back, secures herself by 'pushing' the father to a corner he used to send her to:

When the wind blows, I feel it

When snow swirls down, I see it

The lovely object I hold in my hand" (lines 15-17)

The women-persona in the poems of Sarah Gambito and Maningning Miclat depend on beingin-itself, such conscious spirit to come to terms with themselves and see beyond what is offered to them. As a result, they were awakened to the call of women's strength. Interestingly, the poets' angles of vision utilized facts and truths about woman's life matter-of-factly to underscore that they intuitively see woman awakening at the slightest touch. The women no longer suffer silently. Their awakening is a necessity, no longer a luxury, but a reinstatement of a female genital.

\section{Woman's resistance}

Cixous (1981) posits that it is a major challenge to contemporary feminism to reconcile the pressures for diversity and difference with those for integration and commonality. Pursuing such an issue further, Irigaray (1985) avers that what obstructs the progression of women's thoughts is the concept of sameness or the ideational result of masculine narcissism and singularity. A woman is a reflection, the same as a man, except in her sexuality, and by extension, female sexuality (paradoxically speaking, is the absence or lack of maleness). Due to pressures on women regarding the issue of 'sameness', a vacuum of women's thoughts, experiences, and writings is thus created. To integrate the experiences and emotions of women all over, sameness must be obliterated. The woman should not be described as not the same as a man-she appears free from anything that connects to men. While women embrace each other and join the rest of their sisters to set the record straight and despite the risks, no woman loses the opportunity to break out of the male imaginary and enter a female one. 
Marjorie Evasco's Caravan of the Water Bearers depicts the consuming theme of anger posed:

We will not forget the evil eyes

Of the storm they raised,

Gutting the grounds, they defended.

We have been trained

To look away too often

When man's flesh, muscle, bone,

Knifed woman to protect

The child's eye from the dust

Of our lord's sin against

Our kind, pretending

Our tears are daughters of the wind

Blowing across no-woman's-land (lines 1-12)

The straightforward emotion revealed in the first line tells that the women-personae declare war against the rule of the dominant male. Women are taken as inferiors and weak, having been 'trained' and deemed pretentious. Their tears are considered daughters of the wind, and to a man's eyes, fleeting, unable to hold shape and hence, cannot last, either. The wind blows across no woman's land- women are even viewed as unimportant. The anger of the woman-persona is further rooted in the metaphorical 'storm' that started earlier in the second line. To Plaza (1982), a woman who instead of fighting the storm accepts it blindly, is the eternal idiot: illogical, mad, prattling. The women- personae in the poem affirm that far from being idiots, they rage, they defy, and they wage a mighty war. They set that the effect on the image of women holds the same, if not greater if the women do not fight against the structured rule. To come up with a lifelong change in a structured society, women must write. Barrowing the words of Kristeva, "They must speak of one language from one pair of lips" (1981, p. 69).

\section{Woman's call to action}

The call to action necessitates a response. It is to strengthen or reinforce a claim, to make firm, to assert. The representative women poets used in this study have expressed themselves beyond the point of awakening but also establish a call to action, supporting women-writers who have started to fight the monopoly of the ruling male. To describe the women poets in this study, in Cixous's words, they "desired to live self from within" (1976, p. 70). They write about themselves and that of the other women to spring forth the sources of their unconscious. Julia Kristeva (1981) describes three phases of feminism, not two, as reported by de Beauvoir in 1949. The first phase means feminism demands economic and professional equality with men. Second, feminism seeks to construct a counter-society in which ethics will be shaped by the female-identified concerns in female time. Lastly, feminism points to the demassification of power (1981). To Kristeva, the autonomous third phase can emerge only because equal rights feminism has become part of women's cultural and political fabric. By extension, following Kristeva's arguments, the representative poets used in this study are in the time/moment of affirmation because they have 
attached to themselves the need for them to fight the (social) structure and anything that goes with it.

Helene Cixous (1981) demands that women write. Cixous identified women's writing as women's own (marked writing) and further points out that men's writings comprise the bulk of the accumulated wisdom of humankind. These thoughts, history tells, have been stamped with the official set of approval, hence, they are no longer permitted to move or change. Thus, for Cixous, feminist writing is not merely a new style of writing, but the very possibility of change for it, too, can serve as a springboard for subversive thoughts, the precursory movement of transformation of social and cultural standards (Kristeva, 1981).

Only women who share the same experience (jouissance) as the woman-persona would see intently what the persona is saying. Maningning Miclat shares the same sentiments that women are creations of their identity. They are from anything the dominant male defines them with. They appear strongest when they join their sisters, declaring freedom from the world. Their time women's time- as Kristeva (1981) puts it, is here and they are stronger than ever. This is an affirmation that women share that sacred space that challenges men's dominance. By being close to the source of her strength, a woman further affirms her strength.

Marra Lanot portrays persona who epitomizes the strength of character. The persona declares independence from the stereotypes created or formed by society. Feminist literary tradition has presented different women's angles of vision. One key point in how women represent themselves is rooted in traditional roles. For some feminist critics, this old paradigm of having women engaged in conventional roles is another patriarchal assumption. The representative poets analyzed in this study, however, think otherwise, as they deconstruct the concept and understanding of the orthodox roles. In doing so, they critically represent themselves in a newer angle of vision or constructs different from the stereotypes.

\section{Conclusion}

Women's representation accounts for their understanding of who they are amidst the stereotyping of the society led by the dominant male. In most cases, women affirm their images to resist male domination and such resistance almost always revolves around jouissance. To feminists, jouissance is repressed, but not obliterated as gleaned from the sample poems.

The select Filipino women poets were able to mirror the images of their women-personae as they share with them these very images. Hence, if the women-personae in their works are free, brave, and unrestrained, they, too, are so. Moreover, the images presented by the women poets in their representative poems are the same, accounting for a better understanding of who they are against the stereotypes of a male-dominated literary region. More importantly, they have attempted to establish a strong articulation of a feminist stance, which is a resistance against subversion and marginality. Inevitably, the result is woman's liberation by abandoning their true selves and that which the patriarchal world dictates.

\section{References}

Allison, M. (2007). Creations and recreations. London: Riser Publishing. 
Boehmer, E. (2005). Stories of women: Gender and narrative in the postcolonial nation. Manchester, UK: Manchester University Press.

Campbell, C. (2000). Is there a women's canon? In D. Smyth (Ed.), The canon in Southeast Asian literatures (pp. 88-98). Richmond, Surrey: Curzon Press.

Chin, G., \& Daud, K. (2018). The Southeast Asian woman writes back: Gender, identity and nation in the Literatures of Brunei Darussalam, Malaysia, Singapore, Indonesia, and the Philippines. Singapore: Springer.

Choi, N. (2019). Women's political pathways in Southeast Asia. International Feminist Journal of Politics, 21(2), 224-248. doi: 10.108o/14616742.2018.1523683

Cixous, H. (1981). Construction or decapitation. Journal of Women in Culture and Society, 7(1), 41-55. https://www.jstor.org/stable/3173505

Coady, R. J., \& Johannessen, J. (2006). The book that changed my life: 71 remarkable writers celebrate the books that matter most to them. New York: Gotham Books.

Csikszentmihalyi, M. (1990). Flow: The psychology of optimal experience. New York: Harper \& Row.

Fialho, O. (2019). What is literature for? The role of transformative reading. Cogent Arts E Humanities, 6(1). doi: $10.1080 / 23311983.2019 .1692532$

Humm, M. (1992). Modern feminisms. New York: Columbia University Press.

Irigaray, L. (1985). This sex, which is not one (C. Porter and C. Burke, trans). New York, Vintage.

Johnson, B. (1985). Language and women. USA: Chicago Press.

Kintanar, T. (1992). Women reading. Feminist perspectives on Philippine literary texts. Philippines: University of the Philippines Press and University Center for Women's Studies.

Kristeva, J. (1981). Women’s Time. Signs: Journal of Women in Culture and Society, 7(1): 13-35.

Millet, K. (1970). Sexual politics. US: Doubleday \& Co.

Oliver, K., \& Walsh, L. (2004). Contemporary French feminism. USA: Oxford University Press.

Plaza, M. (1982). French Feminism. NY. Pantheon Books.

Sartre, J. P. (1956). Being and Nothingness (H. E. Barnes, trans). New York: Philosophical Library.

Wright, C. (2017). Skeletons in the Closets: Gay Themes in Philippine Fictions in English. Rupkatha Journal on Interdisciplinary Studies in Humanities, 9(2). doi: 10.21659/rupkatha.v9n2.30

Wright, C., \& Hilario, J. (2016). The mechanisms of defenses: Mistresses in the Philippine contemporary narratives. Journal of Sciences, Technology, and Arts Research, 2(2), 15-24.

Jennie V. Jocson, PhD is currently the Vice President for Academics of Philippine Normal University. While serving as the Vice President, she also holds key positions at Literature Educators Association of the Philippines and Philippine Educational Measurement and Evaluation Association. She was the former Deputy Director of Research Center for Teacher Quality in the Philippines, a partnership between the Philippine Normal University and the University of New England Australia, supported by the Australian Government. 